\title{
DET NORDISKA \\ UNIVERSITETSADMINISTRATÖRSSAMARBETET NORDIC ASSOCIATION OF UNIVERSITY ADMINISTRATORS
}

c/o Åbo Akademi

Domkyrkotorget 3

20500 Åbo (Finland)

Tel: (21) 654741

Fax: (21) 517553

Electronic Mail: INTERNET: jnikula abo.fi,

EARN/BITNET jnikula finabo

Administrative Director: Roger Broo

Head of Bureau: Johan Nicula

Membership of the Association comprises institutions of higher education that maintain research at the highest level. Its aim is to strengthen and extend the relations between the Nordic universities on all administrative levels. This is mainly done by arranging professional seminars and workshops for different groups of university administrators.

Principal publications: Information
Brochure (biannually); seminar reports, information letter to the members (two times a year).

Les membres de l'Association nordique des administrateurs d'université comprennent les institutions de l'enseignement supérieur qui pratiquent la recherche au plus haut niveau. L'objectif de l'Association est de renforcer et d'élargir les relations entre les universités nordiques à tous les niveaux administratifs. Cette action est menée principalement par l'organisation de séminaires et d'ateliers professionnels destinés à différents groupes d'administrateurs universitaires.

Publications principales: "Brochure d'information" (bi-annuelle); rapports de séminaires, lettre d'informations aux membres (deux fois par an). 